\section{MIG WELDING GUIDE}

\section{BY}

\section{R. RAVI}

This is a unique book in the sense it is fully devoted to MIG welding only. As many of you are aware, MIG welding is being used increasingly in many applications. So a book fully devoted to this topic is probably the need of the hour.

The authors have vast experience in this field and the book also contains chapters written by other experts. So in essence the book exposes one to a rich experience in this field.

One of the interesting features of this book, which I felt, was its simple descriptions and explanations together with very good diagrams. The book is divided in to three sectionsTechnologies, Quality and Safety Issues and Applications. There are several sub sections within this group.

The book begins with the process details including the transfer modes, effects of shielding gases and also on hybrid welding methods involving MIG process. This is followed with the equipment details for MIG welding like different power sources, advanced computer controls and their utility, synergic machines, wire feeder technologies etc. A separate chapter on shielding gases follows. A very useful chapter which gives many details on this topic. There is a separate table giving various effects of different shielding gases and gas mixtures along with the recommended gases for various materials. Consumables form an important part in successful MIG welding. The next chapter is devoted to this aspect. The authors have included a chapter on FCAW also since they feel that both MIG and FCAW are closely related in many ways. This is a bonus for us since we get to know many details of this process also in the same book. The first section ends with details on special processes like MIG brazing and Pulsed MIG welding.

The second section begins with methods to achieve higher productivity like TIME, Rapid processing, LINFAST, Cored wires, Double and multi wire, Hybrid welding. Brief details on these methods should help in generating sufficient interest in the reader's mind for exploring further possibilities in his set up. QC and testing methods, safety details are covered in this section. Use of MIG welding many a times reduces costs and there is a separate chapter detailing this along with formulas for calculation.
The third section deals with practical applications of MIG welding in industrial scenario. Since MIG welding is not merely restricted to carbon steels, the book deals with MIG welding applications for other materials like Al, $\mathrm{Cu}, \mathrm{Ni}$, Coated steels, High strength steels, Stainless steels. Automation is a specific advantage associated with MIG welding and details of automating the process and robotics are given in detail spread out in two chapters. In fact in many place schematic diagrams bring clarity to the concept. Details of allied equipments like sensors etc are also given. Typical applications in automobile and heavy vehicle industries form separate chapters and detail many applications used in these industries.

To conclude, I would like to rate this book as par excellent, particularly for MIG welding. The book not only deals with fundamentals, of which many are familiar, but also with advanced techniques which are not still quite popular. That way one stands to gain by reading this book. Since the topics have not been dealt in a highly theoretical manner, it is a good read for those in the industries. It is a "must read and own" book for those who use MIG welding in their day-to-day activities.

\begin{tabular}{|c|c|c|c|c|c|}
\hline \multicolumn{6}{|c|}{ ADVERTISEMENT TARIFF (Effective from April 2007 issue) } \\
\hline \multicolumn{3}{|c|}{ COLOUR ADS ON ART PAPER } & \multicolumn{3}{|c|}{ ORDINARY (Black \& White) } \\
\hline \multirow{3}{*}{$\begin{array}{l}\text { No. of Insertions } \\
\text { Front Cover }\end{array}$} & \multirow{4}{*}{$\begin{array}{c}\text { ONE } \\
\text { No Advertisement } \\
\text { Rs. } 12,000 /-\end{array}$} & \multirow{4}{*}{$\begin{array}{c}\text { FouR } \\
\text { No Advertisement } \\
\text { Rs. } 40,000 /-\end{array}$} & \multirow{4}{*}{$\begin{array}{l}\text { Fuil Page } \\
\text { Half Page } \\
\text { Quarter Page }\end{array}$} & \multirow{4}{*}{$\begin{array}{l}\text { Per Insertion } \\
\text { Rs. } 2,700 /- \\
\text { Rs. } 1,800 /- \\
\text { Rs. } 900 /-\end{array}$} & \multirow{4}{*}{$\begin{array}{l}4 \text { Insertions } \\
\text { Rs. } 9,000 /- \\
\text { Rs. } 6,750 /- \\
\text { Rs. } 3,400 /-\end{array}$} \\
\hline & & & & & \\
\hline & & & & & \\
\hline Back Cover & & & & & \\
\hline Front Inside & Rs. $10,000 /-$ & Rs. $36,000 /-$ & \multirow{4}{*}{$\begin{array}{l}\text { Format of Journal } \\
\text { Size of Journal } \\
\text { Print Area } \\
\text { Column Width } \\
\text { Composed by }\end{array}$} & & \\
\hline Back Inside & Rs. $10,000 /-$ & Rs. $36,000 /-$ & & $27 \times 21 \mathrm{~cm}$ & \\
\hline Centre Spread & & & & $23.2 \times 17.5 \mathrm{c}$ & m \\
\hline (Two Full Page) & Rs. $12,000 /-$ & Rs. $40,000 /-$ & & DTP System & \\
\hline Full Page & & & \multirow{3}{*}{$\begin{array}{l}\text { Mechanical Data } \\
\text { Front Cover } \\
\text { Other Cover / Pages } \\
\text { Centre Spread }\end{array}$} & LengthWidth & \\
\hline (Reverse of Centre Spread) & ) Rs. 7,500/- & Rs. $25,000 /-$ & & $19.0 \mathrm{~cm}$ & $18.0 \mathrm{~cm}$ \\
\hline Full Page & Rs. $7,000 / \cdot$ & Rs. $23,000 /-$ & & $\begin{array}{l}23.0 \mathrm{~cm} \\
23.0 \mathrm{~cm}\end{array}$ & $\begin{array}{l}17.5 \mathrm{~cm} \\
39.0 \mathrm{~cm}\end{array}$ \\
\hline
\end{tabular}

